\title{
Działania Rzecznika Praw Obywatelskich w zakresie problematyki osób zaginionych
}

\author{
AleKSANDRA WentKoWSKA \\ ORCID: 0000-0001-7631-2615 \\ Pełnomocnik Terenowy Rzecznika Praw Obywatelskich w Katowicach \\ Instytut Nauk Prawnych Uniwersytetu Śląskiego w Katowicach
}

Mała Marta zgubiła się podczas wycieczki w góry; starszy pan, cierpiący na chorobę Alzheimera, wyszedł z domu i nie powrócił; grzybiarz zaginął w lesie; Maja została uprowadzona spod supermarketu... Te i inne przypadki składają się na liczbę prawie dwudziestu tysięcy osób rocznie zaginionych $\mathrm{w}$ Polsce, $\mathrm{z}$ których nigdy nie odnajduje się około dwóch tysięcy ${ }^{1}$.

W Polsce utworzono system poszukiwań osób zaginionych i zadbano o ustawowe uporządkowanie działań podejmowanych w celu ich odnalezienia. W policji wypracowano procedury postępowania w wypadku otrzymania zawiadomienia o zaginięciu osoby i prowadzenia czynności poszukiwawczych, zwłaszcza w stosunku do dzieci. W komendzie głównej policji stworzono komórkę odpowiedzialną za ogólnopolską koordynację poszukiwań, określono również strukturę nadzoru nad poszukiwaniami osób zaginionych. Centrum Poszukiwań Osób Zaginionych Komendy Głównej Policji na podstawie bieżącej współpracy z funkcjonującymi na terenie kraju specjalistycznymi grupami poszukiwawczo-

1 Strona internetowa policji: http://statystyka.policja.pl/st/wybrane-statystyki/zaginieni/50885,Zaginieni.html (dostęp: 1.04.2020). 
-ratowniczymi oraz dzięki prowadzonym wspólnie na terenie kraju szkoleniom, działaniom i ćwiczeniom dysponuje na bieżąco uzupełnianą bazą kontaktową wszystkich grup poszukiwawczych. Policja stale udoskonala system poszukiwania osób zaginionych. W dniu 1 lipca 2018 roku weszło w życie Zarządzenie nr 48 Komendanta Głównego Policji z dnia 28 czerwca 2018 roku w sprawie prowadzenia przez Policję poszukiwania osoby zaginionej oraz postępowania w przypadku ujawnienia osoby o nieustalonej tożsamości lub znalezienia nieznanych zwłok oraz szczątków ludzkich. W zarządzeniu wprowadzono nowe rozwiązania i procedury wspierające poszukiwania osób zaginionych oraz wpływające bezpośrednio na skuteczność i efektywność wykonywanych przez policję czynności związanych z poszukiwaniem osób zaginionych oraz identyfikacją osób o nieustalonej tożsamości i niezidentyfikowanych zwłok.

Na skutek wnoszenia przez obywateli spraw indywidualnych Rzecznik Praw Obywatelskich podejmuje tematy dotyczące ochrony praw obywatelskich w licznych wystąpieniach generalnych do ministra spraw wewnętrznych lub komendanta głównego policji. Poniższe zestawienie niektórych problemów pojawiających się na tle szeroko pojmowanego zjawiska zaginięć ma na celu zobrazowanie jedynie niewielkiego jego wycinka z perspektywy działań Rzecznika Praw Obywatelskich. Stąd zostaną przedstawione przykładowe sprawy podzielone według ich sposobu podjęcia i prowadzenia na: wnioskowe, urzędowe oraz generalne. Badanie tych spraw pozwala zapoznać się z niektórymi problematycznymi aspektami zaginięć zarówno w kontekście indywidualnym, jak i generalnym.

\section{Kompetencje Rzecznika Praw Obywatelskich}

Rzecznik Praw Obywatelskich zgodnie z art. 208 ust. 1 Konstytucji RP stoi na straży wolności i praw człowieka i obywatela określonych w Konstytucji i innych aktach normatywnych. Zgodnie z treścią art. 1 ust. 3 ustawy o Rzeczniku Praw Obywatelskich², w sprawach dotyczących ochrony wolności i praw człowieka i obywatela Rzecznik bada, czy wskutek działania lub zaniechania organów, organizacji i instytucji,

2 Ustawa z dnia 15 lipca 1987 roku o Rzeczniku Praw Obywatelskich, tekst jednolity Dz.U. 2017 poz. 958 (ustawa o RPO); P. Winczorek, Komentarz do Konstytucji Rzeczypospolitej Polskiej z dnia 2 kwietnia 1997 r., Warszawa 2000, s. 265. 
zobowiązanych do przestrzegania i realizacji tych wolności i praw, nie nastąpiło naruszenie prawa, a także zasad współżycia społecznego i sprawiedliwości społecznej.

Zakres działania RPO obejmuje czuwanie nad przestrzeganiem praw obywatelskich (w znaczeniu subiektywnym), a nie nad przestrzeganiem prawa (w znaczeniu obiektywnym) w ogólności. Należy podkreślić, iż Rzecznik nie stoi na straży szeroko pojętej zasady praworządności, lecz wyłącznie na straży wolności i praw człowieka i obywatela. Działając jako „kontroler"3 , bada, czy wskutek działania lub zaniechania organów nie nastąpiło naruszenie prawa ${ }^{4}$, a także zasad współżycia i sprawiedliwości społecznej ${ }^{5}$. Właściwość Rzecznika obejmuje zatem wyłącznie sprawy dotyczące ochrony wolności i praw człowieka i obywatela, a od 1 stycznia 2011 roku również realizacji zasady równego traktowania ${ }^{6}$.

RPO w wypadku naruszenia zasady równego traktowania przez organy władzy publicznej, stosownie do przepisów art. 80 i art. 208 Konstytucji RP, przepisów ustawy o RPO oraz przepisów ustawy o wdrożeniu niektórych przepisów Unii Europejskiej w zakresie równego traktowa-

3 S. Trociuk, Komentarz do ustawy z dnia 15 lipca 1987 r. o Rzeczniku Praw Obywatelskich (Dz.U. 2001, nr 14, poz. 147), Warszawa 2005, s. 14.

4 Rozumianego zgodnie z przyjętą przez Konstytucję RP w art. 87 koncepcją źródeł powszechnie obowiązującego prawa (Konstytucja, ustawy, ratyfikowane umowy międzynarodowe, rozporządzenia, akty prawa miejscowego).

5 ,w tym przypadku chodzi o prawo rozumiane proobywatelsko, a więc ukształtowane zgodnie z zasadami aksjologicznie nieobojętnej wykładni, raczej systemowej i funkcjonalnej, niż językowo-gramatycznej. Dlatego Rzecznik nigdy nie przeciwstawia systemowi prawa - systemu sprawiedliwości. Punktem wyjścia dla jego kontroli jest zawsze legalność korygowana tylko względami sprawiedliwości” — RPO/12606/88/VII.

6 Ustawa z dnia 3 grudnia 2010 roku o wdrożeniu niektórych przepisów Unii Europejskiej w zakresie równego traktowania, Dz.U. 2010 Nr 254, art. 17b. Do zakresu działania Rzecznika, dotyczącego realizacji zasady równego traktowania, należy również: 1) analizowanie, monitorowanie i wspieranie równego traktowania wszystkich osób; 2) prowadzenie niezależnych badań dotyczących dyskryminacji; 3) opracowywanie i wydawanie niezależnych sprawozdań i wydawanie zaleceń odnośnie do problemów związanych z dyskryminacją. Zob. szerzej na ten temat: S. Trociuk, Komentarz do ustawy z dnia 15 lipca 1987 r. o Rzeczniku Praw Obywatelskich (Dz.U. 2001, nr 14, poz. 147), stan prawny na dzień 1 grudnia 2007, LEX/el. 2007; por. z Opinią prawną Biura Analiz Sejmowych z dnia 18 października 2010 roku o projekcie ustawy o wdrożeniu niektórych przepisów Unii Europejskiej w zakresie równego traktowania (druk sejmowy nr 3386) aspekty publicznoprawne, aspekty ustrojowe, aspekty cywilnoprawne. 
nia, może podejmować środki wskazane w ustawie o RPO w postaci podjęcia sprawy, wskazania wnioskodawcy przysługujących środków działania, przekazania sprawy według właściwości lub niepodjęcia sprawy ${ }^{7}$. W dalszej kolejności Rzecznik może:

1) podjąć działania procesowe;

2) zainteresować się sprawą z punktu widzenia prawidłowości jej załatwienia, w sytuacji gdy może żądać przedłożenia informacji o stanie sprawy prowadzonej przez sądy, a także prokuraturę i inne organy ścigania oraz żądać wglądu do akt sądowych i prokuratorskich lub akt innych organów ścigania po zakończeniu postępowania i zapadnięciu rozstrzygnięcia;

3) podjąć działania generalne, kiedy na skutek wielu skarg RPO zwraca się do właściwego organu o usunięcie uchybienia, w związku z czym może skierować wystąpienie do organu, organizacji lub instytucji, w działalności których stwierdził naruszenie wolności i praw człowieka i obywatela;

4) podjąć działania kontrolne, kiedy może się zwrócić do organu nadrzędnego nad jednostką z wnioskiem o zastosowanie środków przewidzianych w przepisach prawa ${ }^{8}$.

Podejmując sprawę, RPO może samodzielnie prowadzić postępowanie wyjaśniające albo też zwrócić się o jej zbadanie do właściwych organów ${ }^{9}$. Wybór sposobu prowadzenia sprawy ma charakter pragmatyczny — powinien doprowadzić do wyjaśnienia, czy doszło do naruszenia wolności i praw. Zwracając się o zbadanie sprawy, RPO powoduje co do zasady uruchomienie przez właściwy organ określonej procedury, która - w wypadku stwierdzenia naruszenia wolności lub praw — powinna doprowadzić do zastosowania przez ten organ przewidzianych przez prawo środków. RPO, działając w tym trybie, może wskazywać kierunki, w których dany organ powinien prowadzić postępowanie, oraz okoliczności, które powinny zostać przeanalizowane w toku badania sprawy wyznacza zatem właściwemu organowi granice, w jakich sprawa powinna być badana, a w szczególności jej zakres przedmiotowy. Na podstawie

7 Art. 11 ustawy o RPO.

8 S. Trociuk, op. cit.; I. Malinowska, Rzecznik Praw Obywatelskich w systemie ochrony praw $i$ wolności w Polsce, Warszawa 2007, s. 169.

9 Art. 12 ustawy o RPO oraz S. Trociuk, Rzecznik Praw Obywatelskich. Komentarz, Warszawa 2016. 
przedstawionych rezultatów prowadzonego postępowania RPO ocenia, czy i jakie dalsze działania powinien podjąć w danej sprawie.

\section{Sprawy indywidualne}

Rzecznik Praw Obywatelskich bada skargi obywateli w sprawach indywidualnych zgłoszone osobiście, drogą pocztową lub elektroniczną. Podejmuje również działania z własnej inicjatywy, w sprawach z urzędu, jeżeli poweźmie informację, iż mogło dojść do naruszenia praw obywatelskich.

Zgodnie $\mathrm{z}$ brzmieniem art. 14 ustawy o RPO po zbadaniu indywidualnej sprawy RPO może zakończyć postępowanie, wyjaśniając wnioskodawcy, iż nie stwierdził naruszenia wolności i praw (art. 14 pkt 1). Może również, po stwierdzeniu naruszenia, skorzystać z postulatywnych środków działania (art. 14 pkt 2 i 3), tj. skierować wystąpienie do organu, organizacji lub instytucji, w których działalności stwierdził naruszenie wolności i praw człowieka i obywatela (wystąpienie takie nie może naruszać niezawisłości sędziowskiej), lub zwrócić się do organu nadrzędnego nad jednostką z wnioskiem o zastosowanie środków przewidzianych w przepisach prawa. Stwierdzając naruszenie wolności i praw, RPO może skorzystać ze środków o charakterze procesowym (art. 14 pkt 4-8), tj.:

1) żądać wszczęcia postępowania w sprawach cywilnych, jak również wziąc udział w każdym toczącym się już postępowaniu — na prawach przysługujących prokuratorowi;

2) żądać wszczęcia przez uprawnionego oskarżyciela postępowania przygotowawczego $\mathrm{w}$ sprawach o przestępstwa ścigane $\mathrm{z}$ urzędu;

3) zwrócić się o wszczęcie postępowania administracyjnego, wnosić skargi do sądu administracyjnego, a także uczestniczyć w tych postępowaniach - na prawach przysługujących prokuratorowi;

4) wystąpić z wnioskiem o ukaranie, a także o uchylenie prawomocnego rozstrzygnięcia w postępowaniu w sprawach o wykroczenia, na zasadach i w trybie określonych w odrębnych przepisach;

5) wnieść kasację od prawomocnego orzeczenia, na zasadach i w trybie określonych w odrębnych przepisach ${ }^{10}$.

10 S. Trociuk, Rzecznik Praw Obywatelskich... 
W wypadkach dotyczących zaginięć w większości skargi dotyczą działań funkcjonariuszy policji oraz innych służb zaangażowanych w poszukiwania. W tych wypadkach RPO, podejmując sprawę, może samodzielnie prowadzić postępowanie wyjaśniające lub zwrócić się o zbadanie sprawy lub jej części do właściwych organów, w szczególności organów nadzoru i prokuratury. $\mathrm{W}$ takich wypadkach regułą w działaniu RPO jest zwrócenie się do właściwego nadrzędnego komendanta policji o zbadanie sprawy na podstawie art. 12 pkt 2 ustawy o RPO. Rzecznik wyznacza wówczas granice oraz zakres badania sprawy. Rzecznik Praw Obywatelskich może wskazywać kierunki, w których organ powinien prowadzić postępowanie, badając sprawę, okoliczności, które powinny zostać przeanalizowane w toku jej badania, a także wskazywać na konieczność proobywatelskiej wykładni przepisów prawa podczas badania sprawy. Wyniki badania sprawy organ nadrzędny przedstawia Rzecznikowi. Od ich analizy RPO uzależnia dalszy tok postępowania, podejmując działania zmierzające $w$ dwóch kierunkach: 1) poinformowanie wnioskodawcy o osiągniętych w jego sprawie efektach (np. usunięciu naruszenia wolności lub praw) i zakończenie sprawy; 2) w wypadku niepotwierdzenia zarzutów przez nadrzędnego komendanta, dalsze samodzielne prowadzenie przez RPO postępowania wyjaśniającego. Ten ostatni kierunek może przybrać formę złożenia zawiadomienia o popełnieniu przestępstwa przez funkcjonariusza policji (na podstawie art. $304 \S 2$ k.p.k.), co implikuje dalszy nadzór nad sprawą poprzez monitorowanie postępowania prowadzonego przez urząd prokuratorski (na podstawie art. 13 ust. 1 pkt 3 ustawy o RPO). Na każdym etapie tego postępowania Rzecznik samodzielnie ocenia — badając akta sprawy — czy wyjaśnione zostały wszelkie istotne okoliczności faktyczne, jak również czy zgromadzony materiał dowodowy został oceniony zgodnie z regułami określonymi w art. 7 k.p.k.

W jednej ze spraw, która wpłynęła do RPO 17 sierpnia 2016 roku, Andrzej B. skarżył się na niedopełnienie obowiązków służbowych przez funkcjonariuszy komisariatu policji w K., co w konsekwencji doprowadziło do śmierci jego syna Pawła B., zaginionego w dniu 25 października 2015 roku $^{11}$. Zaginiony Paweł B. był osobą cierpiącą na zaburzenia

11 II.519.865.2016. 
psychiczne i epilepsję. Pomimo natychmiastowego zgłoszenia tego faktu policji, zdaniem interesanta nie podjęto odpowiednich działań pozwalających na odnalezienie Pawła B. w czasie umożliwiającym udzielenie mu pomocy, na skutek czego Paweł B. zmarł. Jak twierdzi interesant, przez okres prawie dwóch miesięcy policja nie podjęła stosownych działań, by odnaleźć Pawła B. W końcu zniecierpliwiona „działaniem” policji rodzina sama zorganizowała akcję, w której wzięli udział m.in. ratownicy Górskiego Ochotniczego Pogotowia Ratunkowego. Po niespełna $30 \mathrm{mi}-$ nutach ciało Pawła B. zostało odnalezione przez grupę GOPR w miejscu, które rzekomo wcześniej wielokrotnie przeszukiwała policja. W odpowiedzi RPO podkreślił, że nie ma prawnych możliwości wzruszenia prawomocnego postanowienia sądu rejonowego dla K. utrzymującego w mocy postanowienie prokuratora rejonowego K. o odmowie wszczęcia śledztwa w sprawie niedopełnienia obowiązków przez funkcjonariuszy policji. Zgodnie ze stanowiskiem Sądu Najwyższego takie postanowienie sądowe nie jest prawomocnym orzeczeniem kończącym postępowanie, zatem nie jest możliwe wniesienie od niego kasacji.

W innej sprawie 30 maja 2017 roku państwo D. skontaktowali się z RPO za pośrednictwem infolinii ${ }^{12}$. Opowiedzieli, że $\mathrm{w}$ niedzielę (28 maja 2017 roku) około godziny 12:00 skontaktowali się z nimi funkcjonariusze policji z komendy miejskiej policji w L. i poinformowali, że zaginęła ich pełnoletnia córka Małgorzata C. Policjanci przekazali rodzicom zaginionej, że w sobotę (27 maja 2017 roku) około godziny 19:45 córka wybrała numer alarmowy i poinformowała, iż zamierza popełnić samobójstwo z powodu niesłusznego odebrania dziecka. Policja nie chciała ujawnić rodzicom zaginionej tych informacji, ale $\mathrm{z}$ toku rozmowy wynikało, że podejmując interwencję na podstawie zgłoszenia telefonicznego, nie zastano Małgorzaty C. w domu. Państwo D. wskazują, że jedyną informacją, jaką otrzymali ze strony komendy miejskiej policji w L. w przedmiocie poszukiwań córki, był fakt trwania poszukiwań. Nie poinformowano ich, jakie czynności zostały podjęte, a policja nie informowała ich o przebiegu poszukiwań, powołując się na okoliczność pełnoletności córki. Rodzice byli bardzo zaniepokojeni, uważając, że w tej sprawie policja działa opieszale i nie wykorzystuje wszystkich dostęp-

12 II.519.591.2017. 
nych środków, które doprowadziłyby do odnalezienia córki. Pan Ryszard D. sugerował policji, żeby sprowadzić psa tropiącego, ale w odpowiedzi usłyszał, że to niemożliwe. Państwo D. domagali się od RPO, aby ten wystąpił do komendy miejskiej w L. z prośbą o informację, co się w sprawie dzieje i jakie są podejmowane czynności, oraz zlecił podjęcie odpowiednich środków w sprawie poszukiwań. Komendant w odpowiedzi poinformował, iż tamtejsza komenda miejska policji prowadziła czynności poszukiwawcze za osobą zaginioną kategorii pierwszej Małgorzatą C. w okresie od dnia 27 maja 2017 roku do dnia 30 maja 2017 roku. Czynności podjęto w dniu 27 maja 2017 roku około godziny 19:45 po informacji telefonicznej od nieustalonej kobiety (zidentyfikowanej w wyniku czynności jako Małgorzata C.) o zamiarze popełnienia samobójstwa. Zawiadomienie o zaginięciu przyjęto w dniu 27 maja 2017 roku od męża zaginionej Piotra C. W godzinach wieczorowo-nocnych niezwłocznie, w trybie doraźnym, w rejonie miejsca zamieszkania przeprowadzono działania penetracyjne, wykorzystując dostępne siły policyjne oraz siły straży pożarnej z jednostek w L., P. oraz K. Czynności przerwano z uwagi na panujące ciemności o godzinie 24:00. W kolejnych dniach kontynuowano działania penetracyjne z wykorzystaniem funkcjonariuszy policji w L., oddziałów prewencji komendy wojewódzkiej policji w P., strażaków oraz ratownictwa wodnego, a także mieszkańców P. Wykorzystano łodzie, sonar do penetracji wody oraz drona. W dniu 28 maja 2017 roku od godziny 6:30 z uwagi na możliwość ujawnienia śladu w działaniach brał udział przewodnik psa służbowego. Ponadto w ramach prowadzonych czynności poszukiwawczych korzystano z innych metod, tj. analizy uzyskanych danych telekomunikacyjnych czy ogłoszeń w środkach masowego przekazu. O fakcie zaginięcia powiadomiono wszystkich policjantów komendy miejskiej w L. oraz jednostki sąsiednie, przeprowadzono także szereg rozpytań w rejonie zaginięcia. W dniu 30 maja 2017 roku około godziny 10:10 w wyniku ponownej penetracji wytypowanych obszarów przez policjantów komendy miejskiej w L. oraz strażaków z ochotniczej straży pożarnej w P. wraz z łodzią funkcjonariusze komendy miejskiej w L. ujawnili $\mathrm{w}$ rowie melioracyjnym na polu po zachodniej stronie P. zanurzone w wodzie zwłoki Małgorzaty C. Z uwagi na identyfikację zwłok czynności poszukiwawczo-identyfikacyjne zakończono. Materiały dotyczące ujawnienia zwłok Małgorzaty C. przekazano do prokuratury rejonowej 
w G. Rzecznik w dalszym ciągu monitorował postępowanie dotyczące śmierci Małgorzaty C. prowadzone przez prokuraturę rejonową w $\mathrm{G}$.

W kolejnej ze skarg na działania policji przesłanej 30 stycznia 2019 roku Adriana G. poszukiwała swojej córki — Joanny D., która miała zaginąć $\mathrm{w}$ Berlinie $^{13}$. Interesantka skarżyła się na brak inicjatywy i działań polskiej policji, która powinna współpracować z policją niemiecką. RPO zwrócił się do komendanta miejskiego policji w L. z prośbą o udzielenie informacji o stanie poszukiwań zaginionej, w szczególności: czy przesłuchano osoby, z którymi ostatnio widziała się zaginiona, czy skontaktowano się z policją w Niemczech i jakie ustalono dalsze przedsięwzięcia w tej sprawie. W odpowiedzi komendant miejski policji w L. wskazał, że czynności zmierzające do zebrania wszelkich informacji mogących przyczynić się do ustalenia miejsca pobytu zaginionej rozpoczęto od momentu pierwszego kontaktu matki zaginionej z funkcjonariuszami policji w L. W związku z tym, że zaginięcie miało miejsce na terenie Berlina, komenda powiatowa policji w L. za pośrednictwem właściwych komórek organizacyjnych policji pozostaje w stałym kontakcie $\mathrm{z}$ policją niemiecką, z którą współpracuje na zasadzie wzajemnej wymiany informacji. W trakcie trwającego postępowania ustalono dane osób, z którymi zaginiona miała ostatnio kontakt i wykonano z ich udziałem stosowne czynności. Po uzyskaniu zgody od ojca zaginionej, który złożył zawiadomienie o zaginięciu, dokonano publikacji informacji o zaginięciu wraz z wizerunkiem Joanny D. w środkach masowego przekazu. Od ojca zaginionej pobrano materiał biologiczny w celu wyizolowania kodu DNA i zarejestrowania go w systemie ewidencyjnym. Sprawa pozostaje w toku.

Podobnie było w sprawie z 23 listopada 2018 roku na skutek wniosku Henryka P. zaniepokojonego losem wnuczki, która rzekomo miała być przetrzymywana wbrew swojej woli w domu publicznym na terenie Niemiec $^{14}$. Jak wynika z informacji otrzymanej z komendy policji w O., miejsce pobytu wnuczki zostało ustalone w dniu 3 maja 2018 roku, ale nie wyraziła ona zgody na przekazanie informacji o swoim miejscu pobytu rodzinie.

\footnotetext{
13 II.519.124.2019.

14 II.519.1112.2018.
} 
Liczne problemy podczas poszukiwań w kolejnej sprawie zgłosiła narzeczona Remigiusza B., zaginionego w nocy z 30 na 31 grudnia 2016 roku w T. ${ }^{15} \mathrm{Z}$ uwagi na okoliczności towarzyszące zaginięciu jedną $\mathrm{z}$ hipotez przyjętych w prowadzonej sprawie było utonięcie zaginionego. Niemniej jednak w związku z tym, że nie ujawniono ciała Remigiusza B., przyjęto również, że mężczyzna mógł oddalić się z miejsca w nieznanym dotąd kierunku. Komendant komisariatu policji w T. dokonał rozpytania osób, które jako ostatnie miały kontakt z zaginionym, przyjaciół i znajomych z pracy, dokonano sprawdzenia szpitali, dworców, noclegowni, schronisk dla bezdomnych oraz izby wytrzeźwień, wielokrotnych penetracji obydwu brzegów rzeki, analiz zapisów monitoringów miejskich oraz monitoringów autobusów miejskich. Na podstawie billingów telefonu komórkowego należącego do zaginionego dokonano weryfikacji prowadzonych przez niego rozmów. O fakcie poszukiwania zaginionego powiadomiono korporacje taksówkarskie, straż miejską, służbę ochrony kolei oraz żandarmerię wojskową. W czynności poszukiwawcze łącznie zaangażowanych zostało ponad stu funkcjonariuszy z różnych jednostek policji, łodzie służbowe oraz psy tropiące i sprzęt specjalistyczny, często niebędący na wyposażeniu policji, a którego użycie możliwe było dzięki zaangażowaniu oraz działaniu wykraczającym poza ustawowe obowiązki funkcjonariuszy policji. Aktualnie sprawa poszukiwawcza za osobą zaginioną jest $\mathrm{w}$ toku, $\mathrm{w}$ dalszym ciągu prowadzone są działania policji mające na celu ujawnienie miejsca pobytu Remigiusza B. Na bieżąco sprawdzano sygnały o możliwych miejscach pobytu zaginionego, a same poszukiwania prowadzone były w skali ogólnokrajowej.

$\mathrm{Z}$ badania powyższych spraw wynika, że z racji sporego obciążenia psychicznego osoby zgłaszające zaginięcie najbliższych nie są w stanie pogodzić się z myślą o ich śmierci czy o zaniechaniu przez nich utrzymywania dalszych kontaktów z rodziną. Trudno w takich wypadkach, w szczególności, gdy nie odnaleziono zwłok, a wszystko wskazuje na to, że osoba zaginiona prawdopodobnie nie żyje, wyjaśnić rodzinie cel i zakres podejmowanych działań (lub ich brak) w ramach systemu poszukiwań osób zaginionych.

15 II.519.145.2017.

Nowa Kodyfikacja Prawa Karnego 56, 2020

(C) for this edition by CNS 


\section{Sprawy z urzędu}

W sprawach podejmowanych z urzędu najczęściej kierowane są pisma do właściwej prokuratury oraz komendanta danej jednostki policji, której sprawa dotyczy, bądź komendanta wojewódzkiego, z prośbą o udzielenie stosownych informacji. Z reguły postępowania wyjaśniające nie potwierdzają zasadności złożonych skarg, mimo to materiały przekazywane są do oceny prokuratorowi, który wszczyna i prowadzi postępowanie przygotowawcze albo odmawia jego wszczęcia.

Niewiele jest spraw dotyczących zaginięć podejmowanych z urzędu. Takim przykładem jest interwencja RPO podjęta na podstawie reportażu Chce znaleźć syna i umrzeć opublikowanego na łamach tygodnika „Przegląd" z 26 października-1 listopada 2015 roku $^{16}$. Sprawa dotyczyła działań policji w zakresie zaginięcia Marcina Sz. po opuszczeniu przez niego komendy powiatowej policji w Kartuzach w dniu 17 lipca 2015 roku. Zwłoki Marcina Sz. odnaleziono w dniu 2 października 2015 roku w pobliżu oczyszczalni ścieków w Kartuzach. Prokuratura okręgowa w Gdańsku prowadziła postępowanie przygotowawcze obejmujące swoim zakresem kwestię doprowadzenia Marcina Sz. do targnięcia się na własne życie oraz niedopełnienia obowiązków służbowych przez funkcjonariuszy komendy powiatowej policji w Kartuzach poprzez niepodjęcie stosownych czynności w związku z prowadzonym postępowaniem poszukiwawczym za zaginionym Marcinem Sz. Z akt sprawy wynikało, że postępowanie zostało przeprowadzone bardzo wnikliwie i zebrany został wszechstronnie cały możliwy materiał dowodowy, z którego bezspornie wynika, że do zgonu Marcina Sz. nie przyczyniły się osoby trzecie, z którym to ustaleniem nie chciała pogodzić się rodzina zmarłego, oskarżając bezpodstawnie o jego śmierć funkcjonariuszy policji. Materiał ten został uzupełniony po uchyleniu przez sąd okręgowy w Gdańsku pierwszego postanowienia o umorzeniu śledztwa - zgodnie ze wskazówkami sądu. Śledztwo ostatecznie zostało umorzone w dniu 21 czerwca 2017 roku wobec stwierdzenia, że czyn nie zawiera znamion czynu zabronionego (odnośnie do art. $231 \S 1$ i art. 151 k.k.), a odnośnie do czynu z art. 156 $\S 3$ k.k. wobec stwierdzenia, że czynu nie popełniono. Brak w związku

16 II.519.1454.2015.

Nowa Kodyfikacja Prawa Karnego 56, 2020

(C) for this edition by CNS 
z tym było podstaw do podejmowania w sprawie dalszych przedsięwzięć ze strony RPO.

\section{Sprawy generalne}

W związku z rozpatrywanymi sprawami RPO może przedstawiać właściwym organom, organizacjom i instytucjom oceny i wnioski zmierzające do zapewnienia skutecznej ochrony wolności i praw człowieka i obywatela i usprawnienia trybu załatwiania ich spraw (art. 6.1). Jest to uprawnienie do formułowania uwag i ocen wykraczających poza ramy sprawy indywidualnej, gdy rozpatrywane sprawy indywidualne wskazują na utrwalającą się po stronie organów i instytucji praktykę stosowania prawa w sposób, który narusza sferę wolności i praw. Rzecznik nie posiada prawa inicjatywy ustawodawczej, może jednak występować do organów, które taką inicjatywę posiadają o jej podjęcie (może to dotyczyć również wydania lub zmiany rozporządzenia czy przepisów prawa miejscowego).

W zakresie zaginięć są to wystąpienia generalne kierowane najczęściej do komendanta głównego policji, ministra spraw wewnętrznych i administracji, a czasem również do prezesa Rady Ministrów. Przykładem takich wystąpień są sprawy dotyczące generalnych zasad poszukiwania osób zaginionych i współpracy służb oraz treningu psów ratowniczych (BPK.501.6.2015).

Już w 2003 roku w związku z coraz liczniejszymi przypadkami zaginięć osób, zarówno dzieci, jak i osób starszych, RPO przekazał komendantowi głównemu policji pismo Fundacji ITAKA, dotyczące problemów związanych z zaginięciami osób oraz istniejącej w tym zakresie sytuacji prawnej, z prośbą o ustosunkowanie się do przedstawionych w piśmie zagadnień, w szczególności do postulatów dotyczących zmiany istniejącego stanu prawnego w powyższej kwestii. Rzecznik prosił również o przedstawienie stanowiska odnośnie do prawidłowości funkcjonowania organów policji w omawianej sprawie, szybkości podejmowanych działań i ich skuteczności ${ }^{17}$.

17 Wystąpienie generalne RPO do Komendanta Głównego Policji, RPO/449052/03/ II/208.1 RZ. 
Badane w kolejnych latach w Biurze Rzecznika Praw Obywatelskich sprawy ujawnily problem dotyczący funkcjonowania oraz działań grup poszukiwawczo-ratowniczych $\mathrm{w}$ zakresie m.in. respektowania przez Krajowy System Ratowniczo-Gaśniczy (KSRG) międzynarodowego certyfikatu IRO (The International Search and Rescue Dog Organisation); organizowania bezpłatnych szkoleń i egzaminów specjalistycznych umożliwiających certyfikowanie grup ochotniczych straży pożarnych i ochotników niezrzeszonych; wspólnych szkoleń i ćwiczeń policji, grup poszukiwawczo-ratowniczych i straży pożarnej (państwowej i ochotniczej) w zakresie organizacji i prowadzenia poszukiwań na otwartym terenie oraz włączenia jednostek samorządu terytorialnego w działania poszukiwawcze na otwartym terenie ${ }^{18}$. Jednym $\mathrm{z}$ najważniejszych czynników mających wpływ na szybkie odnalezienie osoby zaginionej i w efekcie uratowanie jej życia jest szybkie zgłoszenie zaginięcia oraz dysponowanie ratowników, co zwiększa szanse na jej przeżycie. Oznacza to również wysoką płynność w przepływie informacji pomiędzy policją a strażą pożarną. $Z$ tego też powodu rozwój działalności poszukiwawczo-ratowniczej następować powinien w takim kierunku, aby zdolność do realizacji działań ratowniczych na poziomie podstawowym stała się powszechna, jak najszybsza i najbardziej skuteczna dla wszystkich podmiotów KSRG. Mając na uwadze powyższe, RPO zwrócił się do ministra spraw wewnętrznych i administracji o rozważenie potrzeby podjęcia działań legislacyjnych, których następstwo miała stanowić nowelizacja obowiązujących przepisów w taki sposób, aby zapewnić sprawne działania szkoleniowo-ratownicze służb odpowiedzialnych za utrzymanie porządku i bezpieczeństwa w zakresie poszukiwania osób zaginionych.

W zainteresowaniu RPO pozostawała również kwestia prowadzenia przez komendanta głównego policji bazy danych DNA, w której gromadzi się i przetwarza m.in. informacje o wynikach analizy DNA zwłok ludzkich o nieustalonej tożsamości (art. 21 a i b ustawy z dnia 6 kwietnia 1990 roku o Policji, Dz.U. 2011, nr 287, poz. 1687) ${ }^{19}$. Rzecznik Praw

18 Wystąpienie generalne RPO do Ministra Spraw Wewnętrznych i Administracji, BPK.501.6.2015.AW.

19 Wystąpienie generalne RPO do Komendanta Głównego Policji, 13 maja 2014, II.519.1348.2014.KSz. 
Obywatelskich zwrócił się z prośbą o informację w sprawie praktyki i procedury wprowadzania do bazy danych wyników analizy DNA ujawnionych zwłok $\mathrm{NN}^{20}$.

$\mathrm{Na}$ wniosek Fundacji ITAKA prowadzona była również sprawa dotycząca potrzeby stworzenia systemu informacji o osobach hospitalizowanych w stanie nagłym, których tożsamości nie można ustalić. Wniosek zawierał postulat stworzenia zintegrowanego systemu informacji o pacjentach trafiających do podmiotów leczniczych w wyżej wymienionych okolicznościach. Jego celem miałoby być umożliwienie rodzinom osób zaginionych ustalenia, czy taka osoba może przebywać w którymś z podmiotów leczniczych, bez konieczności osobnego dzwonienia do każdego z nich. W związku z tym zwrócono się do Ministerstwa Zdrowia z prośbą o zajęcie stanowiska w sprawie, czy istnieje potrzeba uruchomienia takiego systemu, lub dodanie opisanej funkcji w istniejącym systemie baz danych oraz o ocenę potencjalnej przydatności takiego systemu ${ }^{21}$.

Inne napływające wnioski obywateli ujawniły problem dotyczący pracy oraz treningów psów ratowniczych wykorzystywanych m.in. w poszukiwaniach osób zaginionych ${ }^{22}$. Obecnie obowiązujące przepisy nie pozwalają bowiem na przeprowadzenie pracy i treningów psów ratowniczych adekwatnych do oczekiwanych od nich rezultatów, w postaci odnalezienia osoby poszukiwanej ${ }^{23}$. Skoro psy ratownicze mają pracować w rejonach leśnych czy górskich, to muszą być w takich warunkach szkolone. Szkolenie psa na lince rozmija się bowiem z celem pracy poszukiwawczej psa. W tym wypadku za wystarczającą można uznać nowelizację art. 166 k.w. Ponadto ratowane dobro, które przyświeca pracy oraz szkoleniu psów ratowniczych, jest zdecydowanie wyższym dobrem niż praca psa myśliwskiego czy pasterskiego. Projektowana zmiana (wzorem unormowań funkcjonujących już w prawodawstwie czeskim i słowackim) ma na celu realizację wymagań niezbędnych dla szkolenia psów ratowniczych i ich wykorzystania w ratownictwie. Mając na uwadze powyższe, RPO zwró-

20 Ibidem.

21 Pytanie do Ministerstwa Zdrowia z dnia 29 lutego 2016 roku do Departamentu Infrastruktury i e-Zdrowia, BPK.7013.6.2015 MP.

22 BPK.519.75.2018.

${ }^{23}$ Art. 166 określa, iż „Kto w lesie puszcza luzem psa, poza czynnościami związanymi z polowaniem, podlega karze grzywny albo karze nagany". 
cił się do ministra środowiska z wnioskiem o rozważenie podjęcia działań legislacyjnych, których następstwem byłaby nowelizacja obowiązujących przepisów w taki sposób, aby zapewnić sprawne działania szkoleniowo-ratownicze służb odpowiedzialnych za utrzymanie porządku i bezpieczeństwa w zakresie poszukiwania osób zaginionych.

We wszystkich powyżej opisanych przypadkach adresaci wystąpień nie przychylili się do wniosków Rzecznika, w najlepszym wypadku stwierdzając lakonicznie, że sugestie proponowane przez RPO będą wzięte pod uwagę przy kolejnych nowelizacjach aktów ustawowych.

\section{$* * *$}

Problem zaginięć jest przedmiotem ożywionej debaty publicznej, zarówno z uwagi na skalę, jak i charakter zjawiska. Ludzie giną bez względu na płeć, wiek, status społeczny, wykształcenie. Część zaginięć to efekt bardziej lub mniej przemyślanej, ale świadomej decyzji takiej osoby. Inne to wynik różnego rodzaju wypadków losowych bądź typowe zagubienia.

Poszukiwanie osób zaginionych jest procesem dynamicznym, a zarazem żmudnym i długotrwałym. Składa się na niego wiele czynników, a zaangażowanych jest wielu uprawnionych uczestników postępowania. Często w sytuacjach zaginięć policja zwraca się do innych podmiotów, np. straży pożarnej, a także działających na zasadzie stowarzyszeń grup poszukiwawczo-ratowniczych, o pomoc w prowadzonych akcjach lub operacjach policyjnych. Ich działania i zasady współpracy określa wiele aktów prawnych i procedur. Mimo to zdarza się, że w trakcie prowadzenia poszukiwań pomiędzy różnymi służbami i grupami pojawiają się problemy i niejasności, na które zwracają uwagę organy kontrolne czy organizacje pozarządowe. Niejednokrotnie organy te działają razem, jednakże brak kompleksowych regulacji, a w szczególności odpowiedniego rozdzielenia kompetencji, może prowadzić do niepotrzebnych sporów o właściwość.

Problematyka z zakresu szeroko pojmowanych sytuacji kryzysowych jest przedmiotem znacznej liczby skarg wpływających do Rzecznika Praw Obywatelskich. W tych sprawach RPO dokonuje analizy obowiązujących uregulowań w praktyce w celu dokonania oceny, czy nie wymagają one zmiany, ponieważ w rzeczywistości okazują się niejednolite, sprzeczne z sobą lub krzywdzące poszkodowanych obywateli. Liczba spraw wpły- 
wających do RPO nie wydaje się jednak wysoka. Powodem takiego stanu rzeczy mogą być: brak świadomości co do możliwości zwrócenia się o pomoc do RPO, przekonanie o braku wystarczających kompetencji RPO, czy też obawa przed represjami ze strony policji. Rzecznik Praw Obywatelskich wielokrotnie podkreślał, że efektywność działania właściwych organów państwa w zakresie nie tylko reagowania na już zaistniałe zdarzenia, ale także prewencji w wypadku zagrożeń, których wystąpienie może wyrządzić nieodwracalne straty dla dóbr prawnie chronionych, jest szczególnie istotna w warunkach globalizacji przestępczości.

\section{Bibliografia}

Malinowska I., Rzecznik Praw Obywatelskich w systemie ochrony praw i wolności w Polsce, Warszawa 2007.

Trociuk S., Komentarz do ustawy z dnia 15 lipca 1987 r. o Rzeczniku Praw Obywatelskich (Dz.U. 2001, nr 14, poz. 147), Warszawa 2005.

Trociuk S., Komentarz do ustawy z dnia 15 lipca 1987 r. o Rzeczniku Praw Obywatelskich (Dz.U. 2001, nr 14, poz. 147), stan prawny na dzień 1 grudnia 2007, LEX/el. 2007. Trociuk S., Rzecznik Praw Obywatelskich. Komentarz, Warszawa 2016.

Winczorek P., Komentarz do Konstytucji Rzeczypospolitej Polskiej z dnia 2 kwietnia 1997 r., Warszawa 2000.

\section{Akty prawne}

Biuro Analiz Sejmowych, Opinia prawna z dnia18 października 2010 roku o projekcie ustawy o wdrożeniu niektórych przepisów Unii Europejskiej w zakresie równego traktowania, druk sejmowy $\mathrm{nr} 3386$.

Pytanie do Ministerstwa Zdrowia z dnia 29 lutego 2016 roku do Departamentu Infrastruktury i e-Zdrowia, BPK.7013.6.2015 MP.

Ustawa z dnia 15 lipca 1987 roku o Rzeczniku Praw Obywatelskich, tekst jednolity Dz.U. 2017 poz. 958.

Ustawa z dnia 3 grudnia 2010 roku o wdrożeniu niektórych przepisów Unii Europejskiej w zakresie równego traktowania, Dz.U. $2010 \mathrm{Nr}$ 254, art. 17 b.

Wystąpienie generalne RPO do Komendanta Głównego Policji, 13 maja 2014 roku, II.519.1348.2014.KSz.

Wystąpienie generalne RPO do Komendanta Głównego Policji, RPO/449052/03/ II/208.1 RZ.

Wystąpienie generalne RPO do Ministra Spraw Wewnętrznych i Administracji, BPK.501.6.2015.AW. 


\section{Źródła internetowe}

Strona internetowa policji: http://statystyka.policja.pl/st/wybrane-statystyki/zaginieni/50885, Zaginieni.html (dostęp: 1.04.2020).

\section{Actions of the Commissioner of Human Rights in Poland in the field of missing persons}

Summary

Based on the motions submitted for the attention of the Commissioner for Human Rights, as well as on the inspected cases, this article discusses the system of searching for missing persons. The Police implemented and continuously improve the system of searching for missing persons. However, the procedures are often imperfect. Sometimes it results in a situation that search procedures are too late, especially in cases in which time is a crucial factor. Hence the question arises as to whether the legal and logistic aspects of searching for missing persons in Poland is well organized. Another question is whether the rules governing search operations are clear and understandable for all the services. To ensure efficient rescue operations undertaken by the services responsible for the maintenance of order and safety in the search for missing persons, the Commissioner for Human Rights asked the Minister of the Interior to take the need for an introduction of some legislative changes into consideration.

Keywords: Commissioner of Human Rights in Poland, missing persons, K-9, Police, SAR (search \& rescue). 